\title{
Bronchial Biopsy
}

National Cancer Institute

\section{Source}

National Cancer Institute. Bronchial Biopsy. NCI Thesaurus. Code C51782.

Removal of tissue from the bronchus for microscopic examination. 